\title{
Geotechnical Properties of Clayey Soil Stabilized with Cement-Sawdust Ash for Highway Construction
}

\section{${ }^{* 1}$ OWAMAH, HI; ${ }^{2}$ ATIKPO, E; ${ }^{3}$ OLUWATUYI, O; ${ }^{4}$ OLUWATOMISIN, AM}

\author{
${ }^{1 \& 2}$ Department of Civil and Environmental Engineering, Delta State University, PMB 1, Abraka, Oleh Campus \\ ${ }^{3 \& 4}$ Department of Civil Engineering, Landmark University, Omu-Aran, Kwara State \\ *Email: owamah.hilary@gmail.com; hiowamah@delsu.edu.ng;+2348035705814
}

\begin{abstract}
The study was conducted to investigate the different effects of cement-sawdust ash and cement on a clayey soil sampled from Mandate Lodge, Landmark University, Omu-Aran, Nigeria. The binder mix of cementsawdust ash (CSDA) was mixed in a ratio of 1:1. The CSDA and cement were added to the soil samples at varying percentages of 1.5, 3.0, 4.0, and 7.0\% by weight of the soil. Atterberg limits and strength tests (unconfined compressive strength (UCS) and direct shear (DS) test) were performed on the samples to determine the suitability of the stabilized soil as a construction material in highway pavement.Atterberg limit test result showed that the addition of $7 \%$ cement decreased the liquid limit from 58\% to $42 \%$ and plasticity index from $18 \%$ to $3 \%$, while the addition of $7 \%$ CSDA decreased the liquid limit from $58 \%$ to $48 \%$ and plasticity index from $18 \%$ to $4 \%$. The atterberg limit test results also showed that the stabilized clayey soil samples met the requirements of the Nigerian General Specifications of maximum plasticity index (PI) of 30\% and liquid limit (LL) of a maximum of 50\% when used as a subgrade material in highway construction. The strength test result showed that the strength values of the samples increased with binder addition and met with the requirement for use as a subgrade material in highway construction.
\end{abstract}

DOI: $\underline{\text { https://dx.doi.org/10.4314/jasem.v21i7.29 }}$

Copyright: Copyright $\left(C_{0} 2017\right.$ Owamah et al. This is an open access article distributed under the Creative Commons Attribution License (CCL), which permits unrestricted use, distribution, and reproduction in any medium, provided the original work is properly cited

Dates: Received 05 April 2017; received in revised form 22 November 2017; accepted 31 December 2017

Keywords: Cement, Saw dust, strength test subgrade material, highway construction

Regular maintenance and total replacement of existing pavements involve large amount of money and hence put a burden on the budgets of transportation ministries/directorates in many countries. Any approach that can reduce construction cost and at the same time increase life cycle of pavements will be helpful for efficient road maintenance. Modern highways are constructed to provide safety and comfort (Butt et al., 2016). Failures on Nigerian highways are generally due to poor geotechnical properties of the underlying soils which constitute the base or sub grade material for the entire road configuration. Necessity to improve soil properties for road building has resulted in the use of various stabilizers (Amu et al., 2010). Use of lime, fly ash, Portland cement, saw dust ash and others or in their combined forms usually leads to soil index properties transformation as a result of particles cementation (Amadi, 2010).

Soils are stabilized for improvement of their durability and strength to render them more suitable for construction (Khalid et al., 2012). For some decades, lime and cement are the two major additives for the stabilization of soils. The cost of the materials has however increased hugely as a result of the high increase in energy cost since 1970s (Neville, 2000).
Much dependence on the use of manufactured soil improving additives like cement, and lime, has made the cost of road construction on stabilized soils huge. Thus, the use of waste materials such as rice husk ash, sawdust ash etc., which are pozzolanic in nature will considerably reduce the cost of construction and as well help in pollution control which is a burning issue world over (Asiagwu et al., 2012).

A number of researchers have studied the use of sawdust ash as a stabilizing binder in soil. Ogunribido (2012) worked on the geotechnical properties of sawdust ash stabilized Southwestern Nigeria lateritic soils. Edeh et al. (2013) did an evaluation of the characteristics of lateritic soil stabilized with sawdust ash. Otoko and Honest (2014) carried out a research on stabilization of Nigerian deltaic laterites with sawdust ash. Butt et al. (2016) researched on the strength behavior of clayey soil stabilized with sawdust ash. In all these studies, one thing was common, the results of laboratory tests show that the properties of the soil improved when stabilized with sawdust ash. However, the effectiveness of the tested product (sawdust ash) is not yet clearly established in practice possibly because sawdust ash stabilized soils did not meet the requirement for use as a highway construction material and hence the main reason for 
this study. This study is aimed at determining the use of a primary binder (cement) in combination with a secondary binder (sawdust ash) in stabilizing a clayey soil for use as an effective highway construction material.

\section{MATERIALS AND METHOD}

Site Description: The clayey soil samples were taken from the front of the Mandate Lodge at Landmark University, Omu-Aran, Kwara State, Nigeria. The area lies at a geographical coordinate of $8.1402^{\circ} \mathrm{N}$ and $5.0963^{\circ} \mathrm{E}$ with an elevation between 495 and 543 metres above sea level.

Stabilizing binder: The binders selected for this study were cement and cement-sawdust ash (CSDA). The cement was gotten from a retailer while the sawdust ash was obtained from the wood in carpentry workshop burnt at $600^{\circ} \mathrm{C}$ for 4 hours in an electric furnace following the procedure in Barathan and Gobinath (2013).

Sample preparation: The clayey soil samples were stabilized with cement and cement-sawdust ash (CSDA) at varying percentages of $0 \%, 1.5 \%, 3.0 \%$, $4.0 \%$, and $7.0 \%$. These values were in the same range as those used by Jauberthie et al (2010). The stabilized samples were allowed to cure for seven (7) days before the strength test were carried out.

Experimental Methods: Soil index property and classification tests namely particle size distribution analysis and Atterberg limit tests were performed on the clayey soil. Atterberg limit tests and strength tests which include direct shear test and unconfined compressive strength test were conducted on the stabilized samples. These tests were conducted at the
Geotechnical Engineering Laboratory of Landmark University, OmuAran, Kwara State in accordance with the American Society for Testing and Materials (ASTM) codes as follows; Atterberg limit tests (ASTM D4318), particle Size Distribution (ASTM D422), direct shear test (ASTM D3080), unconfined compressive strength test (ASTM D2166).

\section{RESULTS AND DISCUSSION}

Soil Characterization Results: For the clayey soil, the percentage passing sieve No. 200 (0.075 mm), No. 40 $(0.425 \mathrm{~mm})$, No. $10(2.00 \mathrm{~mm})$ and No.4 (4.75mm) were $38.5 \%, 60.3 \%, 81.75 \%$ and $96.4 \%$ respectively. The particle size distribution of the clayey soil is shown in Figure 1. The Atterberg (consistency) limit of a soil is for showing that state of the soil with respect to its water content. The combined plot of the liquid limit and plasticity index of the stabilized clayey soil as a function of the cement and CSDA content is as shown in Figure 2. The liquid limit (LL) slightly decreased with increase in the cement and CSDA content, although the decrease was more when the clayey soil was stabilized with $7 \%$ cement (that is $27.6 \%$ ) than when it was stabilized with $7 \%$ CSDA (that is $17.2 \%$ ). The plasticity index (PI) which gives a measure of the plasticity of a soil, also decreased just like the LL with an increase in the cement and CSDA content. The decrease in the PI value was more when the clayey soil was stabilized with $7 \%$ cement $(83.3 \%)$ than when it was stabilized with $7 \%$ CSDA (that is $77.8 \%$ ). Cement and CSDA application to the clayey soil led to the exchange of hydrated monovalent cations in the contaminated soil with the divalent cations (such as $\mathrm{Ca}^{2+}$ and $\mathrm{Mg}^{2+}$ ) in the cement. Beetham et al. (2014) stated that "the valence of the charge-balancing cations, among several other factors, primarily controls the thickness of the DDL".

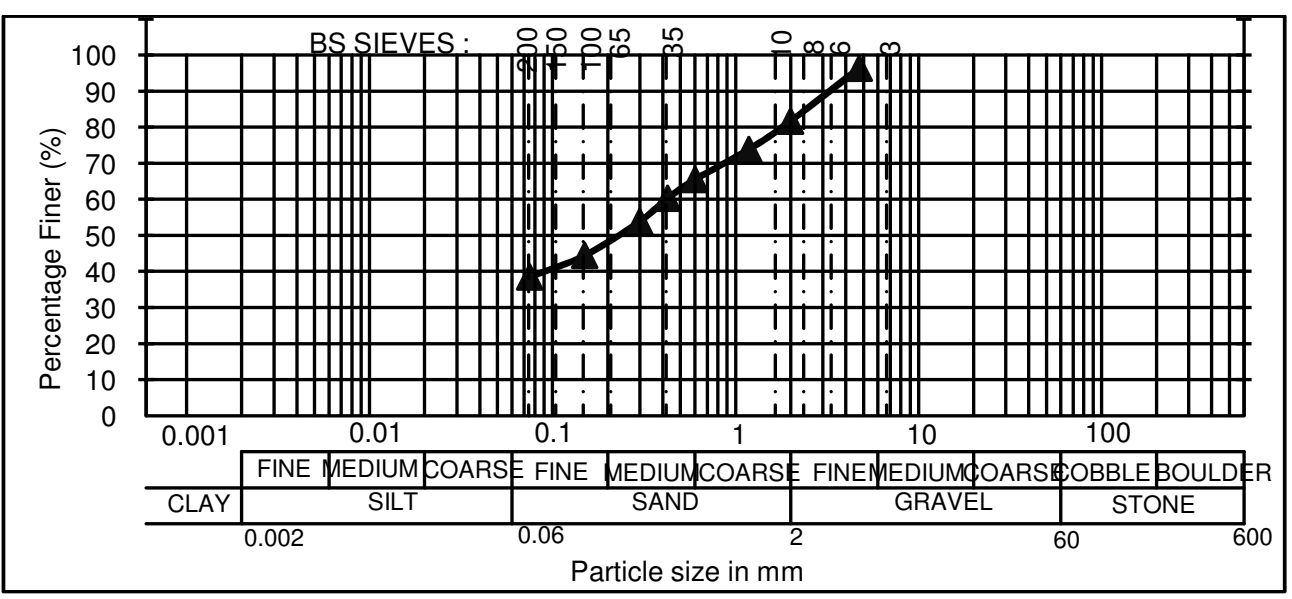

Fig 1. Particle size distribution for the clayey soil samples 
Consequently, such balancing of the clay surface charges balancing with divalent cations has been found capable of reducing DDL thickness (Bohn, 2002), and could be the reason for the decrease in the plasticity index of the stabilized clayey soil. The decrease in the atterberg limit values were in accordance with the results obtained in Portelinha et al. (2012) and Oyediran and Okosun (2013). From fig 3 , the plot of the clayey soil ( $0 \%$ cement or CSDA) was within the AASHTO plasticity chart for clay soil. As the cement or CSDA content is increased in the soil sample, the plot progressively shifted closer to the silt portion of the chart. The 7\% cement and 7\% CSDA stabilized soil were classified as A-5 and A-2-5 soils according to the AASHTO plasticity chart in Figure 3. A-5 and A-2-5 soils are both good subgrade materials for highway construction. Both $7 \%$ cement and 7\% CSDA stabilized clayey soil samples met the requirements of the Nigerian General Specifications for highways (FMW\&H, 1997) of maximum plasticity index of $30 \%$ and liquid limit of a maximum of $50 \%$ for soils used as a subgrade material in road construction.

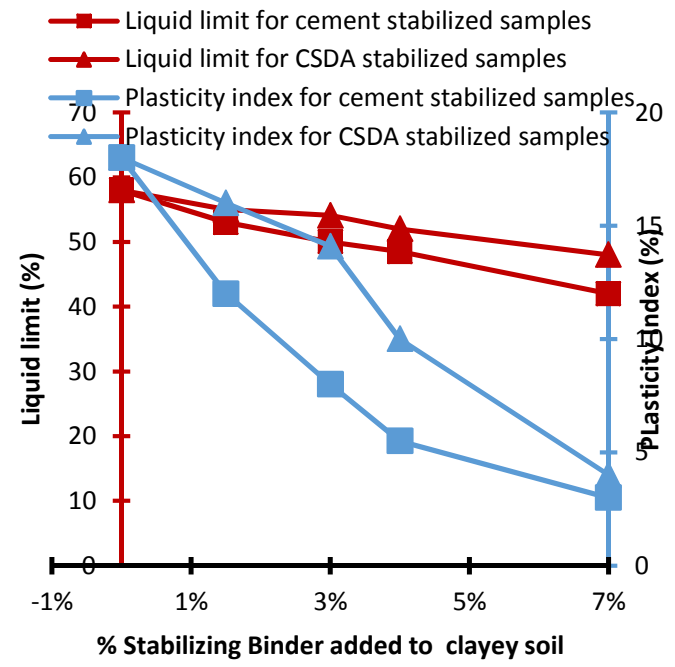

Fig 2.Atterberg limit values for stabilized clayey soil samples

Strength Test Results: The results from the direct shear test showing the cohesion and angle of internal friction values of the stabilized clayey soil samples are shown in Figure 4. The results showed that both the cohesion and angle of internal friction values increased with increase in the cement and CSDA content. The increase in cohesion values was more when the clayey soil was stabilized with $7 \%$ cement (that is $150 \%$ ) than when it was stabilized with 7\% CSDA (that is $122.2 \%)$. The angle of internal friction which is a stress dependent component also had an increase. The increase was more when the clayey soil was stabilized with $7 \%$ cement $(24.9 \%)$ than when it was stabilized with 7\% CSDA (that is $14.2 \%$ ).

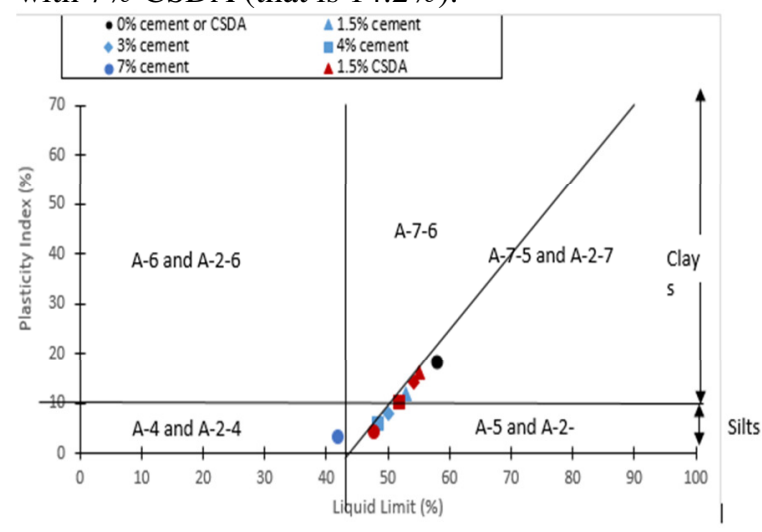

Fig 3. AASHTO plasticity chart showing plots of atterberg limit values of stabilized clayey soil samples

The plots of the unconfined compressive strength (UCS) test at different curing days for the cement and CSDA stabilized clayey soil samples are shown in Figure 5. The results showed that the UCS values increased with increase in the cement and CSDA content. This increase in strength was due to the binder (cement and CSDA) added which had cementitious properties solidifying the soil matrix, thereby increasing the strength values of the clayey soil samples. The increase in the strength values of the stabilized soil samples were similar to those reported in Amu et al. (2011) and Ogunribido (2012). Figure 5 also showed that the curing of the stabilized soil samples led to an increase in their UCS values. The increase in UCS values was more when the clayey soil was stabilized with $7 \%$ cement (that is $516.1 \%$ ) than when it was stabilized with $7 \%$ CSDA (that is $288.4 \%$ ). The UCS values of the $7 \%$ cement and CSDA stabilized clayey soil met the requirement of $687-1373 \mathrm{kN} / \mathrm{m}^{2}$ for sub-base as specified by Ingles and Metcalf (1972). This also implies that the stabilized samples are not only a good subgrade material in highway pavement, they are also good subbase material.

Conclusion: Result obtained from this study shows that the Atterberg limits decreased with increase in the binder content. The Atterberg limit values of the 7\% stabilized clayey soil met the requirements of the Nigerian General Specifications for highways of maximum plasticity index of $30 \%$ and liquid limit of a maximum of $50 \%$ for soils used as a subgrade material in road construction. The strength values of the stabilized clayey soil samples also showed an increase with increase in the stabilizing binder (cement and CSDA) content and were found suitable as sub-base or subgrade material in a highway pavement. 


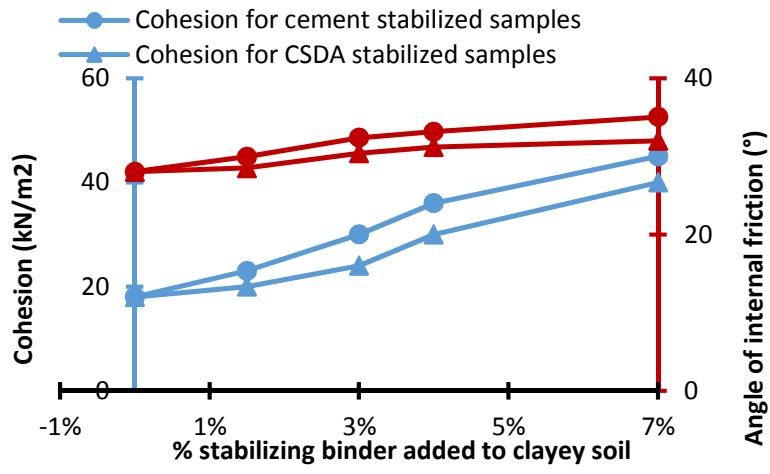

Fig 4. Cohesion and angle of internal friction values from direct shear test of stabilized clayey soil samples

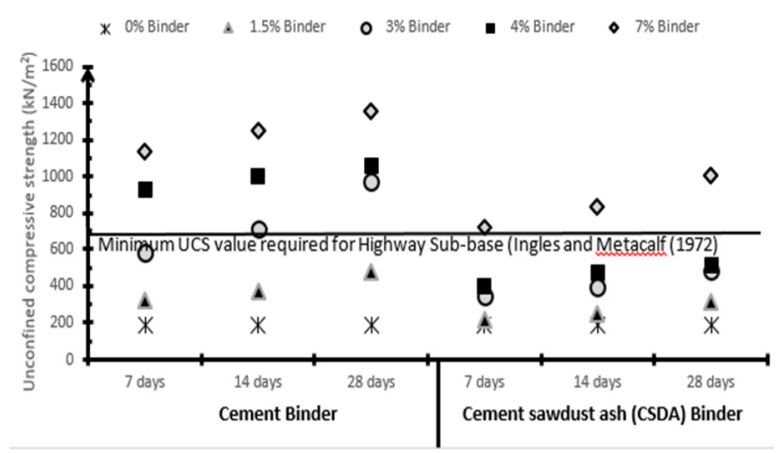

Fig 5. Unconfined compressive strength values of stabilized clayey soil samples

\section{REFERENCES}

Amu, OO; Ogunniyi, SA; Oladeji, OO (2011). Geotechnical properties of lateritic soil stabilized with sugarcane straw ash. American J. Sci. Ind.Res. (2):323-331.

Asiagwu, AK, Owamah, HI, Illoh, VO (2012). Kinetic and thermodynamic models for the removal of aminophenol (dye) from aqueous solutions using groundnut (Arachishypogea) shells as the biomass. Adv. Appl. Sci. Res. 3 (4): 2257-2265

Barathan, S; Gobinath, B (2013). Evaluation of wood ash as a partial replacement tocement. Inter. J. $f$ Sci. Engineer. Technol. Res. 2(10).

Beetham, P; Dijkstra, T; Dixon, N (2014). Lime stabilization for earthworks: a UK Perspective. Proceedings of the Institution of Civil Engineers Ground Improvement, 168(2): 81-95.
Bohn, HL (2002). Soil Chemistry. Wiley, New York, NY, USA.

Butt, WA; Gupta, K; Jha, JN (2016). Strength behavior of clayey soil stabilized with saw dustash. Inter.J. Geo-Engineer. 7(1): 18.

Edeh, JE; Agbede, IO; Tyoyila, A (2013). Evaluation of Sawdust Ash-Stabilized LateriticSoil as Highway Pavement Material. J. Mat. Civil Engineer. 26(2): 367-373.

Federal Ministry of Works and Housing (1997). Nigerian general specifications for roads andbridges. Federal Highway Department; 2, 145-284.

Ingles, OG; Metcalf, JB (1972). Soil StabilizationPrinciples and PracticeButterworths. Sydney, NSW $374 p p$.

Jauberthie, R; Rendell, F; Rangeard, D; Molez, L (2010).Stabilization of estuarine silt withlime and/or cement. Applied Clay Science50 (3):395400.

Khalid, N; Mukri, M; Kamarudin, F; Arshad, MF (2012). Clay soil stabilized using WastePaper Sludge Ash (WPSA) mixtures. Electronic J. Geotechnical Engineer. 17, 1215-1225.

Ogunribido, THT (2012). Geotechnical Properties of Saw Dust Ash Stabilized SouthwesternNigeria Lateritic Soils. Environ. Res., Engineer. Manage. 60(2):29-33.

Otoko, G R; Honest, B K (2014). Stabilization of Nigerian Deltaic Laterites with Saw Dust Ash. Inter. J. Sci. Res. Manage. 1287-1292.

Oyediran, IA; Okosun, J. (2013). An attempt to improve geotechnical properties of some highway lateritic soils with lime. $R M Z-M \& G$ 60: 287-296.

Portelinha, FHM; Lima, D C; Fontes, MPF;\& Carvalho, CAB. (2012). Modification ofa Lateritic Soil with Lime and Cement: An Economical Alternative for Flexible Pavement Layers. Soils and Rocks, Sao Paulo 35(1):51-63. 